\title{
Foulant analysis of hollow fine fiber (HFF) membranes in Red Sea SWRO plants using membrane punch autopsy (MPA)
}

\author{
Troy N. Green ${ }^{\mathrm{a}, \mathrm{b}, *}$, Ibrahim Al-Tisan ${ }^{\mathrm{a}, \mathrm{b}}$, Mahmoodur Rahman ${ }^{\mathrm{a}, \mathrm{b}}$, Yaser Al-Jehani ${ }^{\mathrm{b}}$, \\ Al-Munther Al-Hakamy \\ aDesalination Technology Research Institute (DTRI), Al-Jubail, Saudi Arabia, email: tgreen@swcc.gov.sa \\ ${ }^{b}$ Saline Water Conversion Corporation (SWCC), Al-Jubail, Saudi Arabia, email: rdc@swcc.gov.sa \\ 'King Abdullah University of Science and Technology, Thuwal, Saudi Arabia, email: almunther.alhakami@kaust.edu.sa
}

Received 21 August 2016; Accepted 26 January 2017

\begin{abstract}
A B S T R A C T
Membrane punch autopsy (MPA) is a procedure for quantitative foulant analysis of hollow fine fiber (HFF) permeators. In the past, quantitative autopsies of membranes were restricted to spiral wound. This procedure was developed at SWCC laboratories and tested on permeators of two commercial Red Sea reverse osmosis plants. For membrane autopsies, stainless steel hollow bore picks were penetrated to membrane cores and fibers extracted for foulant analysis. Quantitative analysis of extracted materials contained inorganic and organic foulants including bacteria. Fourier transform infrared spectroscopy analysis confirmed the presence of organic fouling functional groups and scanning electron microscopy with energy dispersive X-ray spectroscopy in the presence of diatoms and silica most likely not from particulate sand. API analysis revealed the presence of Shewanella and two Vibrio microbial species confirmed by $16 \mathrm{~S}$ rDNA sequence library. It was observed that fouling content of HFF cellulose triacetate (CTA) membranes were more than 800 times than polyamide spiral wound membranes.

Keywords: SWRO; Membrane punch autopsy; SEM/EDX; Hollow fine fiber; Biofilm; Bacteria; Red Sea; Organic foulant; OPEX; CAPEX
\end{abstract}

\section{Introduction}

Industrial membranes store records of tangible information reflecting plant operation, environmental disturbances and process failures that can compromise product production. Destructive membrane autopsies are preformed to gain a qualitative and quantitative understanding of feed water effects on permeators. Spiral wound (SW) and hollow fine fiber (HFF) membranes are the prevailing permeators used for seawater reverse osmosis (SWRO). Though much SWSWRO ex-situ quantitative membrane autopsy information exists, foulant quantification for HFF-SWRO membranes remained challenging. Most HFF membrane foulant analysis methods are qualitative and therefore incapable of providing

\footnotetext{
* Corresponding author.
}

axial/radial quantitative foulant information over time. A novel attempt to quantitate membrane foulants was introduced by Ishizuka using non-destructive forward cleaning extraction [1]. In a bench-scale experiment, membrane surface foulants were collected and quantified after comparative physical and chemical cleaning methods. Results are promising but the attempt is mostly qualitative relating fouling to membrane resistance.

This paper establishes to new method for foulant quantification of HFF membranes using destructive membrane punch autopsy (MPA). This method is not exclusive and can be used for permeators of different brands or models. Detailed operational parameters and conditions for both plants have been discussed [2,3].

Autopsies were carried out on membranes of two plant locations of similar operational configurations and

Presented at the International Desalination Association (IDA) Conference, San Diego, USA, 30 August-4 September 2015. 


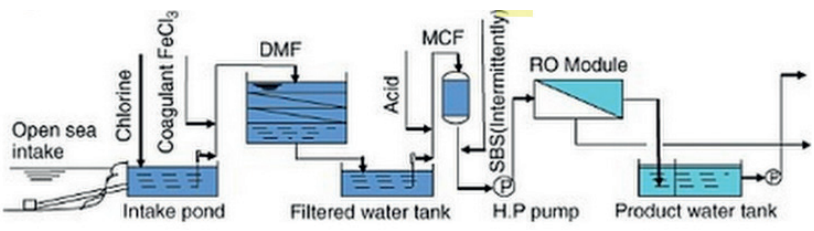

Fig. 1. Typical SWRO plant configuration (Red Sea, Saudi Arabia).

Table 1

Important plant operation parameters

\begin{tabular}{|c|c|c|}
\hline Plant operations & $\begin{array}{l}\text { Jeddah SWRO } \\
\text { plant }\end{array}$ & $\begin{array}{l}\text { Al-Birk SWRO } \\
\text { plant }\end{array}$ \\
\hline Capacity (m³/day) & $5.68 \mathrm{E}+04$ & $2.27 \mathrm{E}+03$ \\
\hline $\begin{array}{l}\text { Feed dosing } \\
\text { chlorine, ppm }\end{array}$ & 2.0 & 3.75 \\
\hline $\begin{array}{l}\text { Residual chlorine } \\
\text { (ICI), ppm }\end{array}$ & 0.50 & 0.50 \\
\hline Anti-scalant, ppm & 40 & 97 \\
\hline SBS (for ICI) & $7 \mathrm{~h}$ on $/ 1 \mathrm{~h}$ off & $\begin{array}{l}(7 \mathrm{~h} \text { on/1 h off }) \\
6.00 \mathrm{ppm}\end{array}$ \\
\hline Flocculent & $\begin{array}{l}\text { Ferric chloride } \\
1.7 \mathrm{ppm}\end{array}$ & Magnifloc 2.30 ppm \\
\hline
\end{tabular}

membrane types with different total product capacities (Fig. 1). Both plants used intermediate chlorination injection (ICI) $7 \mathrm{~h}$ on/ $1 \mathrm{~h}$ off. Membranes were cellulose triacetate-hollow fine fiber (CTA-HFF) elements from the same manufacture. Chemical pretreatment consisted of chlorination, acid dossing, ferric chloride flocculation and SBS dosing to manage ICI (Table 1) [3]. Physical pretreatments consist of intake screens, dual media filters (DMF) and cartridge filters. In both plants, pretreated water was pumped to membranes at a feed pressure of 60 bar. After an approximate period of $2.50 \times 10^{4} \mathrm{~h}$ of operation, membranes were extracted, and punch autopsied.

The purpose of MPA is to provide a quantitative method for autopsy of HFF membranes. This is important to understanding fouling impact as a function of plant operation, pretreatment and membrane configurations. Foulant quantification and distributions are important in accessing membrane capital expenditures (MBR CAPEX) and membrane operating expenditures (MBR OPEX). Before this method, HFF membrane autopsies were qualitative. MPA offers a quantitative method for HFF membrane autopsies.

\section{Experimental setup}

MPA is an invasive method for permeator autopsies of HFF membranes. It allows quantification of biological, chemical and biochemical species associated with permeators. Stainless steel bore picks are penetrated to a membrane core and excised (Fig. 2). Hollow picks contain fibers that are transferred to a $250-\mathrm{mL}$ flask containing sterile filtered $\mathrm{ddH}_{2} \mathrm{O}$. A dipstick ruler is inserted into membrane shafts to

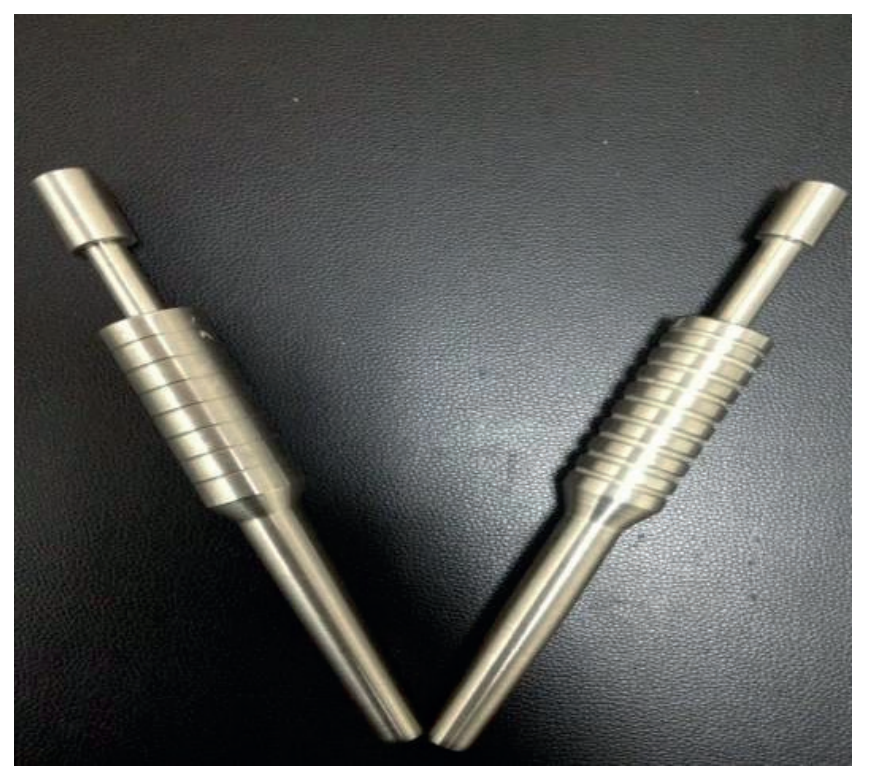

Fig. 2. Membrane punch autopsy devices.

measure depth of penetration to cores. Foulant concentrations can be determined per unit area.

Membrane fibers suspended in $\mathrm{ddH}_{2} \mathrm{O}$ are vortex and sonicated to dissociate foulants [4]. Suspended foulants are decanted and process repeated until fibers appear unstained. Decant is collected, volume measured, then assayed for biocide tolerance and organic/inorganic biofilm content. Cleaned fibers are air dried and placed in a desiccator pending microscopic evaluation and intrinsic viscosity analysis.

Biofilm associated bacteria are isolated, enumerated, purified and identified with API and 16S rDNA sequence library [5]. Chlorine sensitivity tests are conducted on biofilm extracts and phenotypically diverse colonies enumerated and purified for biochemical identification.

\subsection{Biocide tests}

Biocide analysis is conducted on biofilm suspensions (containing microbial isolates) after $30 \mathrm{~min}$ exposure with and without chlorine (at various $\mathrm{pHs}$ in sterile seawater and sterile double distilled water). From decanted biofilm extract, $1 \mathrm{~mL}$ is transferred to $9 \mathrm{~mL}$ of $\mathrm{ddH}_{2} \mathrm{O}$ and serial diluted. From serial diluted tubes, $1 \mathrm{~mL}$ of biofilm/bacteria stock is transferred to tubes containing $9 \mathrm{~mL}$ of chlorinated aseptic seawater and $\mathrm{ddH}_{2} \mathrm{O}$ at different pHs. Controls are prepared from non-chlorinated aseptic seawater and $\mathrm{ddH}_{2} \mathrm{O}$ and spiked with serial diluted bacterial stock (from biofilm extract).

Biocides is prepared from a stock solution of sodium hypochlorite and assayed to $0.3 \mathrm{mg} / \mathrm{L}(\mathrm{pH} 6.6)$ and $0.55 \mathrm{mg} / \mathrm{L}$ ( $\mathrm{pH} 5.5)$ in seawater medium and $0.16 \mathrm{mg} / \mathrm{L}(\mathrm{pH}$ 6.7) and $0.55 \mathrm{mg} / \mathrm{L}$ ( $\mathrm{pH} 6.2$ ) in $\mathrm{ddH}_{2} \mathrm{O}$ medium. After 30 min exposure, test and control vials (containing bacteria without chlorine) are platted on MAA (Difco marine agar $2216+5 \%$ agar) and incubated for $24 \mathrm{~h}$. Colonies are quantified by colony forming units per $\mathrm{mL}(\mathrm{CFU} / \mathrm{mL})$ and identified using API and $16 \mathrm{~S}$ rDNA sequence library [5]. 


\subsection{Organic chemical analyses}

\subsubsection{CTA-HFF membrane}

Organic analysis is conducted by modified methyl tertiary-butyl ether (MTBE) extraction [6-8] substituting liquid chromatography-mass spectrometry injection for base/ acid precipitation. Foulant suspensions used in preparation for the chorine test are thoroughly vortexed and transferred to $100 \mathrm{~mL}$ flasks containing $75 \mathrm{~mL}$ MTBE. The mixtures are slowly transferred to $250 \mathrm{~mL}$ separation funnels. Next, $15 \mathrm{~mL}$ of $1 \mathrm{M} \mathrm{HCl}$ is slowly added (phase separation observed). Samples are mildly agitated and periodically vapor purged.

Aqueous phase is transferred to $100 \mathrm{~mL}$ glass beakers, and above process repeated twice (beginning with addition of $15 \mathrm{~mL}$ of $1 \mathrm{M} \mathrm{HCl}$ [to pre-extracted organic phase]). For each sample set, aqueous extracts are combined and $10 \mathrm{M}$ of $\mathrm{NaOH}$ added dropwise to precipitate organic bases. Precipitations of organic bases are further enhanced by refrigeration. Suspended organics are sieved onto pre-cleaned, dried and pre-weighed $47 \mathrm{~mm}$ Whatman GF/C filters. Filtered suspensions are aseptically air dried (in a desiccator) and weighed to record extraction masses.

The remaining organic phases are extracted from solvents by adding $15 \mathrm{~mL}$ of $1 \mathrm{M}$ sodium bicarbonate solution $\mathrm{NaHCO}_{3}$ to pre-extracted organic phases (after the acid extraction). After the third extraction, aqueous phases are combined and precipitated with $10 \mathrm{M} \mathrm{HCl}$ (dropwise additions). To the remaining organic phases (containing MTBE), $15 \mathrm{~mL}$ of $1 \mathrm{M} \mathrm{NaOH}$ (strong base) are dosed with slow mixing and periodic purging. After the third extraction, aqueous phases are collected in sample set beakers and precipitated with $10 \mathrm{M} \mathrm{HCl}$ (dropwise additions). Suspended organics are filtered (on pre-cleaned, dried and pre-weighed $47 \mathrm{~mm}$ Whatman GF/C filter papers). Filters with residuals are aseptically air dried (in a desiccator) and weighed to record extracted masses. Organic contents from sample sets are weighed, and the two highest mass categories from organic extracts are subjected to Fourier transform infrared (FTIR) analysis.

\section{Results}

\subsection{Biofilm bacteria identification}

Four colonies were isolated from the Al-Birk and Jeddah SWRO plants. Of the four isolated colonies, Shewanella and two Vibrio species were present in both plants' membrane autopsies. The fourth species was unidentifiable and associated with membranes from the Al-Birk SWRO plant. Samples from the Al-Birk plant were subjected to chlorine tolerance tests.

\subsubsection{Chlorine tolerance test}

Biofilm samples from autopsied membranes spiked with chlorine appeared to have bacteria concentrations (CFU) more than $93 \%$ (Table 2) of controls when seawater was chlorinated to $0.28 \mathrm{ppm}$ (at $\mathrm{pH}$ 6.6). Bacteria concentrations were $>82 \%$ when seawater was chlorinated to $0.55 \mathrm{ppm}$ (at $\mathrm{pH} 5.5$ ).

Bacteria density (CFUs) was $89 \%$ (Table 3) more than the control when distilled water was chlorinated to $0.16 \mathrm{ppm}$ (at $\mathrm{pH}$ 6.7) and $82 \%$ more when chlorinated to $0.55 \mathrm{ppm}$ (at $\mathrm{pH}$ 6.2). As chlorine concentrations increased from 0.16 to 0.55 ppm, CFUs decreased. Concentrations were higher than blanks giving the impression of bacterial proliferation in presence of chlorine. This warrants further investigation. Chlorine

Table 2

CFUs of biofilm bacteria in chlorinated seawater (after 30 min exposure)

\begin{tabular}{llll}
\hline Bacterial isolates & $\begin{array}{l}\text { Blank seawater } \mathrm{pH} 6.1 \\
\text { (purified isolates }[\mathrm{CFU} / \mathrm{mL}])\end{array}$ & $\begin{array}{l}\text { Seawater 0.28 ppm chlorine } \mathrm{pH} 6.60 \\
(\mathrm{CFU} / \mathrm{mL})\end{array}$ & $\begin{array}{l}\text { Seawater 0.55 ppm chlorine pH 5.50 } \\
(\mathrm{CFU} / \mathrm{mL})\end{array}$ \\
\hline Colony I & $1.81 \mathrm{E}+06$ & $3.28 \mathrm{E}+07$ & $6.05 \mathrm{E}+06$ \\
Colony II & $1.21 \mathrm{E}+06$ & $1.83 \mathrm{E}+07$ & $4.54 \mathrm{E}+06$ \\
Colony VI & $2.57 \mathrm{E}+05$ & $5.21 \mathrm{E}+06$ & $5.54 \mathrm{E}+06$ \\
Colony VII & $1.76 \mathrm{E}+06$ & $1.64 \mathrm{E}+07$ & $1.16 \mathrm{E}+07$ \\
Total & $5.34 \mathrm{E}+06$ & $7.27 \mathrm{E}+07$ & $2.78 \mathrm{E}+07$ \\
\hline
\end{tabular}

Note: Colony I: Schewanella; Colony II: Vibrio P.; Colony VI: Vibrio; and Colony VII: Unknown.

Table 3

CFUs of biofilm bacteria in chlorinated $\mathrm{ddH}_{2} \mathrm{O}$ (after 30 min exposure)

\begin{tabular}{llll}
\hline Bacterial isolates & $\begin{array}{l}\text { Blank ddH } \\
\text { (purified isolates }[\mathrm{CFU} / \mathrm{mL}])\end{array}$ & $\begin{array}{l}\mathrm{ddH}_{2} \mathrm{O} \mathrm{0.16} \mathrm{ppm} \mathrm{chlorine} \mathrm{pH} \text { 6.74 } \\
(\mathrm{CFU} / \mathrm{mL})\end{array}$ & $\begin{array}{l}\mathrm{ddH}_{2} \mathrm{O} 0.55 \mathrm{ppm} \text { chlorine } \mathrm{pH} \text { 6.20 } \\
(\mathrm{CFU} / \mathrm{mL})\end{array}$ \\
\hline Colony I & $9.58 \mathrm{E}+05$ & $1.36 \mathrm{E}+07$ & $5.88 \mathrm{E}+06$ \\
Colony II & $9.32 \mathrm{E}+05$ & $9.07 \mathrm{E}+06$ & $2.35 \mathrm{E}+06$ \\
Colony VI & $3.78 \mathrm{E}+05$ & $4.87 \mathrm{E}+06$ & $4.70 \mathrm{E}+06$ \\
Colony VII & $2.32 \mathrm{E}+06$ & $1.36 \mathrm{E}+07$ & $1.23 \mathrm{E}+07$ \\
Total & $4.59 \mathrm{E}+06$ & $4.11 \mathrm{E}+07$ & $2.52 \mathrm{E}+07$ \\
\hline
\end{tabular}


did not have a collective or colony based biocide impact on biofilm suspensions in seawater or in $\mathrm{ddH}_{2} \mathrm{O}$. CFU concentrations of chlorine treated bacteria in $\mathrm{ddH}_{2} \mathrm{O}$ are generally less than those in chlorine treated seawater. A 9\% reduction in CFUs is observed for chlorinated bacteria in $\mathrm{ddH}_{2} \mathrm{O}$ than in chlorinated seawater at $0.55 \mathrm{ppm}$. A $14 \%$ reduction in CFUs is observed in control samples, which may be attributed to impact of osmotic shock from microbial exposure to hypotonic solution [9].

\subsection{Membrane analysis}

\subsubsection{Membrane foulant content (SEM/EDX)}

SEM EDX analysis was conducted for CTA-HFF foulants in the Al-Birk and Jeddah Red Sea plants. At the Al-Birk plant, large amounts of foulant were observed. Upon SEM/EDX inspection, major elements consist of oxygen (38.0\%), carbon $(31 \%)$, silica (13\%) and iron (6\%). At the Jeddah plant, pressure vessels contained two membrane elements in series. Average foulant percent compositions in feed elements (first elements) were oxygen $(45 \%)$, silica $(29 \%)$, carbon $(16 \%)$, sodium $(6 \%)$, barium (5\%) and zinc (3\%). Silica was abundant in the feed end of the feed element with an abundance of carbon in the brine end of the feed element. In brine elements (second elements) major elemental constituents contained oxygen (33\%), carbon $(27 \%)$, iron $(22 \%)$ and silica (13\%). Silica presence was unexpected (as particulate sand should be captured in first element). However, SEM revealed the presence of diatoms, which may explain the presence of silica peaks.

\subsubsection{Membranes foulant content (organic extraction at Al-Birk and Jeddah plants)}

At Al-Birk, average foulant weight on feed-end orientation of membranes was approximately $63 \mathrm{mg} / \mathrm{cm}^{3}$ (Table 3)

\section{Table 4}

Foulant concentrations from punch autopsy of the Al-Birk and Al-Jeddah Plants

\begin{tabular}{lcl}
\hline Stations & $\begin{array}{l}\text { Concentration } \\
\text { total foulant } \\
\left(\mathrm{mg} / \mathrm{cm}^{3}\right)\end{array}$ & $\begin{array}{l}\text { Concentration } \\
\text { organic foulant } \\
\left(\mathrm{mg} / \mathrm{cm}^{3}\right)\end{array}$ \\
\hline Al-Birk feed-end element & 63.44 & 32.09 \\
Al-Birk brine-end element & 35.76 & 20.92 \\
Jeddah feed element & 123.46 & 52.50 \\
Jeddah brine element & 134.68 & 23.89 \\
\hline
\end{tabular}

and $36 \mathrm{mg} / \mathrm{cm}^{3}$ at the brine end. Thus, feed ends of membranes contained $43 \%$ more foulant mass than brine ends. In Jeddah plant, average feed element deposits weighted 124 and $134 \mathrm{mg} / \mathrm{cm}^{3}$ for brine element deposits. Thus, the brine membranes contained $7 \%$ more fouling mass than its feed membranes (in series configuration).

In Al-Birk, the average organic foulant content was $32 \mathrm{mg} / \mathrm{cm}^{3}$ in feed ends of elements and $21 \mathrm{mg} / \mathrm{cm}^{3}$ in brine ends of elements (Table 4) making the feed $34 \%$ greater in organic fouling content. In the Jeddah SWRO plant, the average organic content of feed elements was $53 \mathrm{mg} / \mathrm{cm}^{3}$ as compared with $24 \mathrm{mg} / \mathrm{cm}^{3}$ in brine elements making feed elements $55 \%$ greater in average organic foulant.

The highest density of total organic content was in feed elements of the series configured membranes of Jeddah plant. In this plant, brine membranes had the highest total fouling density with the lowest organic foulant concentrations and consequently the lowest percentages of organic foulants (Fig. 3). These membranes tend to have lower organic fouling and more inorganic foulants. This is consistent with results observed for brine elements in series configurations. Conversely, Al-Birk membranes had the highest percentage of organic foulants and the lowest total foulant and organic foulant concentrations (Fig. 3).

Further analysis of organic components from membranes through MTBE acid/ base extraction were illuminating. In Al-Birk Plant, the highest average concentration of organics were acid extracted foulants $\left(9 \mathrm{mg} / \mathrm{cm}^{3}\right)$ followed by residuals remaining in MTBE solvent $\left(8 \mathrm{mg} / \mathrm{cm}^{3}\right)$. This was followed by foulants from weak base extracts $\left(6 \mathrm{mg} / \mathrm{cm}^{3}\right)$ and strong base extracts $\left(4 \mathrm{mg} / \mathrm{cm}^{3}\right)$, respectively (Table 4$)$.

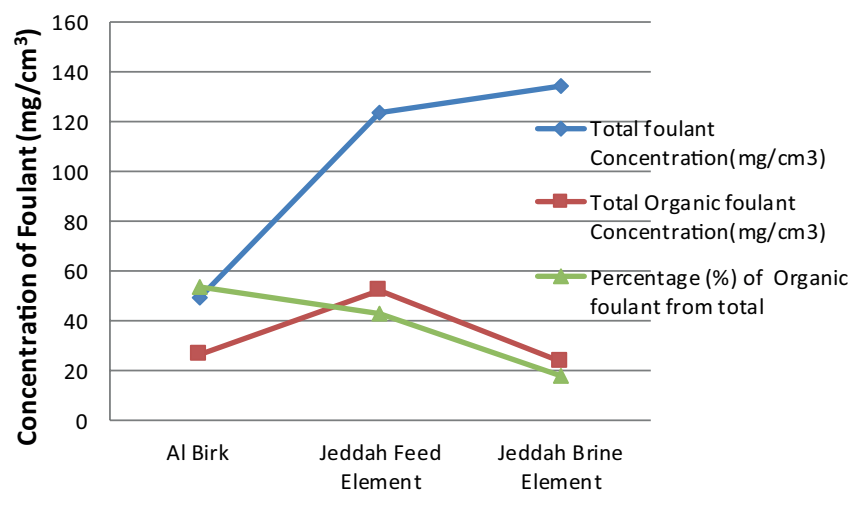

Fig. 3. Average foulant densities from punch autopsy elements of Al-Birk and Jeddah.

Table 5

Organic foulant distributions from punch autopsy from Al-Birk and Jeddah plants

\begin{tabular}{lccll}
\hline Membrane location & \multicolumn{4}{l}{ Mass distributions of organics from membrane foulants } \\
\cline { 2 - 5 } & $\begin{array}{l}\text { Foulant density retained } \\
\text { in organic solvent } \\
\left(\mathrm{mg} / \mathrm{cm}^{3}\right)\end{array}$ & $\begin{array}{l}\text { Foulant density } \\
\text { from aid extraction } \\
\left(\mathrm{mg} / \mathrm{cm}^{3}\right)\end{array}$ & $\begin{array}{l}\text { Foulant density from } \\
\text { weak base extraction } \\
\left(\mathrm{mg} / \mathrm{cm}^{3}\right)\end{array}$ & $\begin{array}{l}\text { Foulant density from } \\
\text { strong base extraction } \\
\left(\mathrm{mg} / \mathrm{cm}^{3}\right)\end{array}$ \\
\hline Al-Birk & 7.455 & 9.26 & 6.05 & 3.74 \\
Jeddah feed element & 18.81 & 19.74 & 7.4 & 6.55 \\
Jeddah brine element & 3.76 & 1.79 & 2.84 & 3.49 \\
\hline
\end{tabular}


In Jeddah feed elements (Table 5), the highest organic concentrations were from acid extractions $\left(20 \mathrm{mg} / \mathrm{cm}^{3}\right)$, followed by those remaining in the organic solvent after extractions $\left(19 \mathrm{mg} / \mathrm{cm}^{3}\right)$. Next, those of weak base extracts (re-extracted from a weak base $\left[7.4 \mathrm{mg} / \mathrm{cm}^{3}\right]$ ) then strong base extracts $\left(6.55 \mathrm{mg} / \mathrm{cm}^{3}\right)$. Organic densities were more abundant in feed elements than brine elements (in these membranes which are series configured).

\subsubsection{Membrane foulant analysis by FTIR (from acid extractions)}

3.2.3.1. Al-Birk membranes FTIR analysis for both feed and brine ends of membranes were similar in representation of functional group spectra with regard to organics extracted with acid (Table 6). The lower frequency of the spectra $1,031 \mathrm{~cm}^{-1}$ is indicative of the silica GF/C standard. Its signal is not strong in comparison with the standard (GF/C filter) because it is masked by a $\mathrm{C}-\mathrm{N}$ stretch from aliphatic amines.
Between the ranges of $1,550-1,700 \mathrm{~cm}^{-1}$ (Fig. 4), amide and carbonic group exist. At 1,552-1,651 $\mathrm{cm}^{-1}$, peaks for proteins and polypeptides are present. At approximately 3,000 $\mathrm{cm}^{-1}$, $\mathrm{C}-\mathrm{H}$ carbohydrate groups are present. Amine groups (from proteins) exist between frequencies 3,100 and $3,600 \mathrm{~cm}^{-1}$. Though spectrum for both feed and brine ends of Al-Birk membranes are similar, there is a difference in intensity, which may be attributed to organic presence.

3.2.3.2. Jeddah membranes Jeddah feed elements contain organic peeks. The silica peak $1,003 \mathrm{~cm}^{-1}$ is slightly masked by the presence of protein amine groups (Fig. 5). Between the ranges of 1,550 and $1,700 \mathrm{~cm}^{-1}$ amide and carbonic groups exist. At approximately $3,000 \mathrm{~cm}^{-1}, \mathrm{C}-\mathrm{H}$ carbohydrate groups are present. There are high amine signals between 3,100 and $3,600 \mathrm{~cm}^{-1}$ stretch. Feed membrane FTIR results for Jeddah are different from brine membranes. In brine membranes, spectrums are similar to GF/C standards with exception of an apparent amine $\left(3,000 \mathrm{~cm}^{-1}\right)$ and $\mathrm{C}-\mathrm{H}$ carbohydrate peek $\left(3,100-3,600 \mathrm{~cm}^{-1}\right)$. Results indicate the possible presence of

Table 6

FTIR results for Al-Birk membranes

\begin{tabular}{llllll}
\hline Membrane orientation & $\begin{array}{l}\text { Silica } \\
\left(\mathrm{cm}^{-1}\right)\end{array}$ & $\begin{array}{l}\text { Amide and carbonic } \\
\text { groups }\left(\mathrm{cm}^{-1}\right)\end{array}$ & $\begin{array}{l}\text { Proteins and polypeptides } \\
\left(\mathrm{cm}^{-1}\right)\end{array}$ & $\begin{array}{l}\text { Carbohydrates } \\
(\mathrm{C}-\mathrm{H})\left(\mathrm{cm}^{-1}\right)\end{array}$ & $\begin{array}{l}\text { Proteins } \\
(\mathrm{N}-\mathrm{H})\end{array}$ \\
\cline { 2 - 6 } & 1,031 & $1,550-1,700$ & $1,552-1,651$ & 3,000 & $3,100-3,600$ \\
\hline Feed end of membrane & 0 & 0 & 0 & 0 & 0 \\
Brine end of membrane & 0 & 0 & 0 & 0 & 0 \\
\hline
\end{tabular}

Note: Strong signal -

Weaker signal -

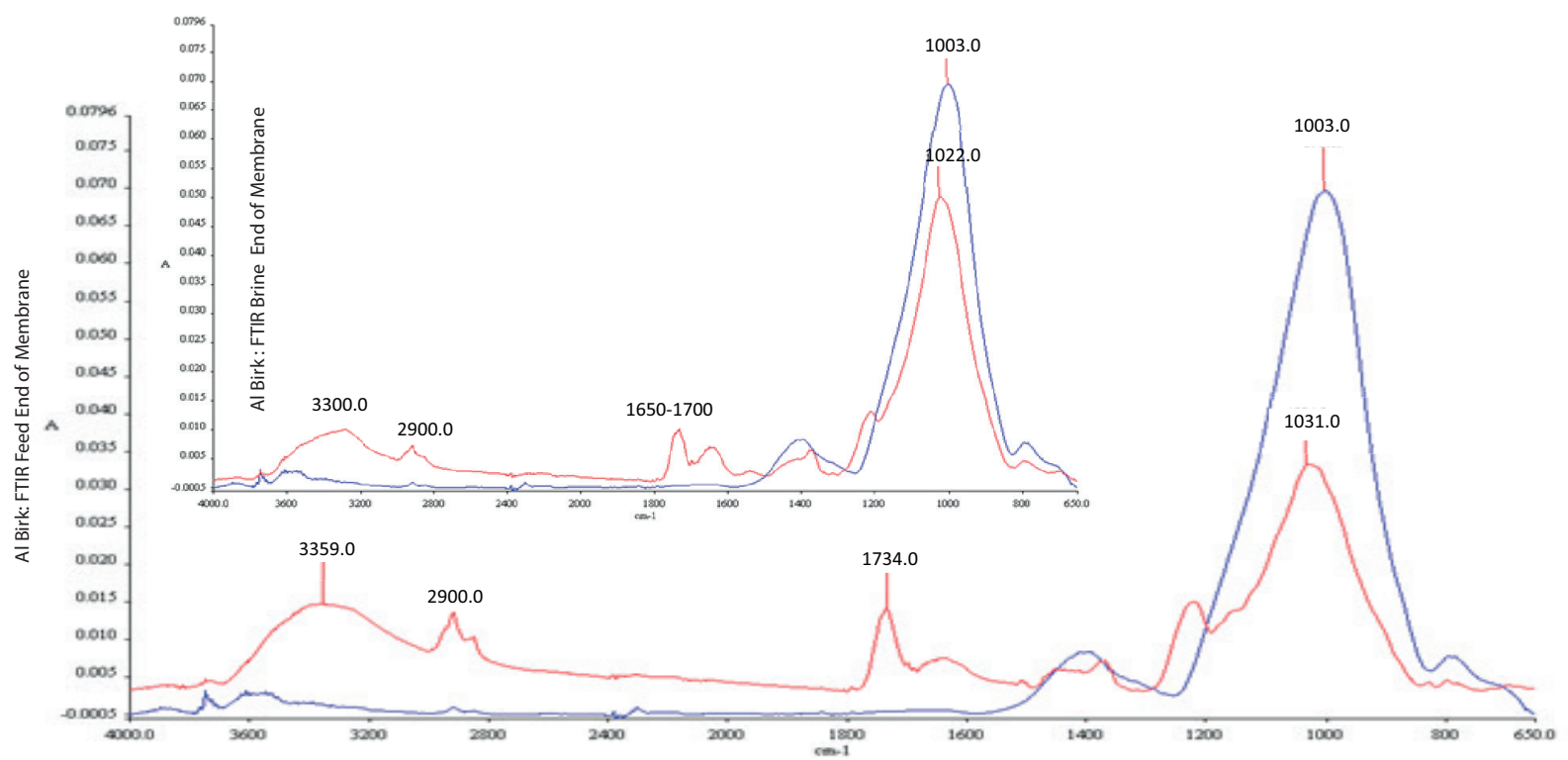

Fig. 4. FTIR analysis of foulants from feed and brine ends of membranes at the Al-Birk commercial SWRO Plant. 


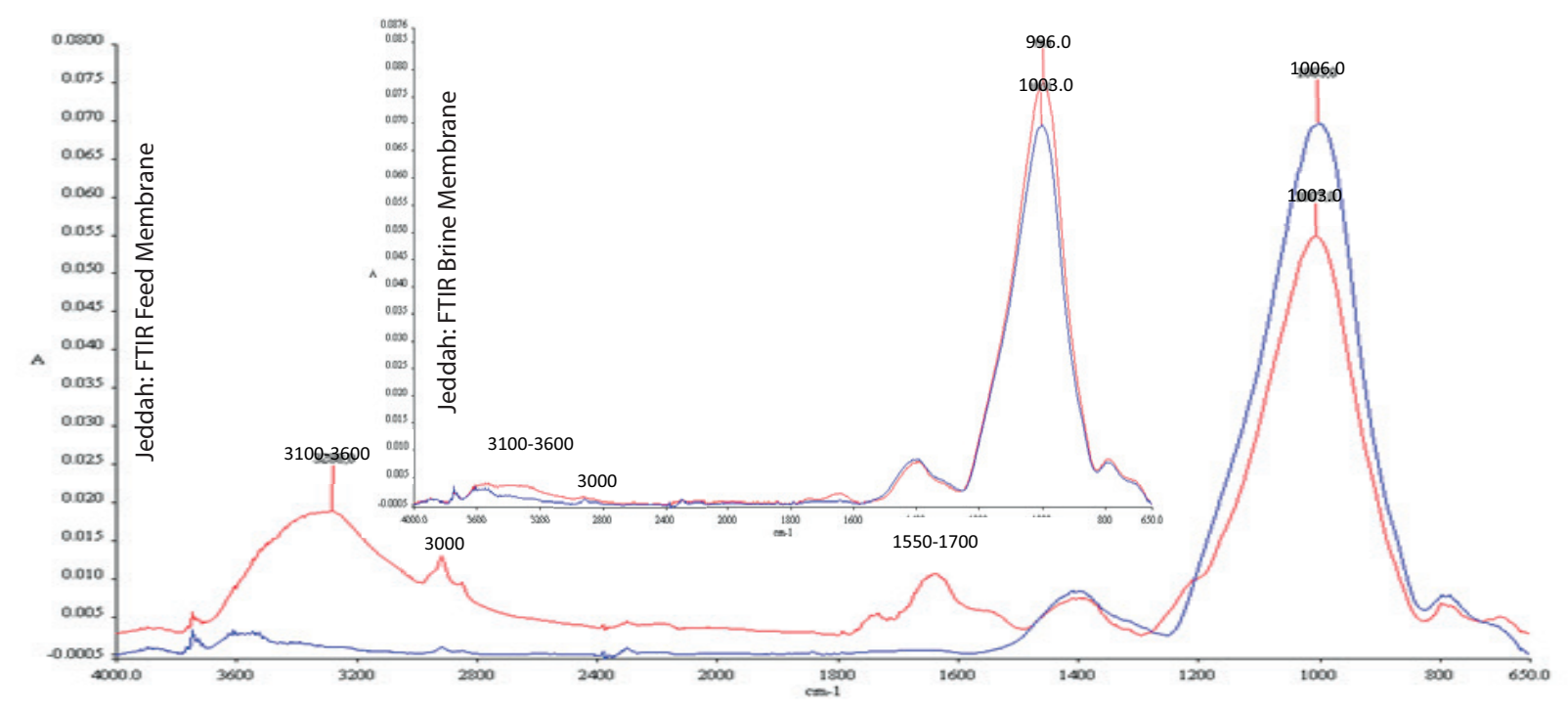

Fig. 5. FTIR analysis of foulants from feed and brine ends of membranes (in series) at the Jeddah commercial SWRO plant.

proteins or sugars, which are typical components of a biofilm matrix. Low intensity may be due to low concentrations.

\section{Discussion}

Four bacterial isolates were identified as part of the fouling milieu. They are Shewanella, two Vibrio species and one unknown. The three known species were isolated in plants studied while the unidentified species was found in the Al-Birk plant.

Chlorine tolerance studies of bacteria (from biofilm suspensions) reveal marine agar growth higher in CFU concentrations than standards. This result was unexpected but considering that samples are not from sessile bacteria but homogenized biofilm in suspension, several plausible explanations that can be suggested. One suggestion is that chlorine may be acting on biofilm digesting micronutrients and liberating bacteria. An increase in bacterial populations resulting from chlorine may not be an indication of growth but liberation of sessile bacteria into the bulk media. Another possibility is that chlorine is being consumed in the reaction with biofilm liberating bacteria (from the matrix) and increasing micronutrients in solution. This may promote growth. Lastly, it may be possible that chlorine is not an effective biocide with regard to biofilm bacteria, which may have metabolic pathways to survive its effect. In some microbes, chlorine may induce a cascade of biochemical effects resulting in the production of organic acids, ligands and lipids that they excrete as protection against external environments [10-12].

Analysis of SWRO membrane biofilms on Al-Birk and Jeddah permeators reveal inorganic and organic foulants. In Jeddah SWRO permeators, inorganics are the main foulants in series configured membranes. Over $57 \%$ and $82 \%$ of feed and brine element foulants, respectively, are inorganics. The amount of inorganic foulants in brine membranes are $36 \%$ more than in feed membranes. This is understandable in series configured permeators that concentrate brine around fibers during desalting and source concentrated brine as feed to the next membrane. The presence of iron, which comprised nearly one-fourth of the inorganic foulants, in the Jeddah plant, was odd. This can be an indication of channeling in DMF and/or overdosing.

Inorganic content of the Al-Birk plant was $47 \%$ of the total foulant mass, which is less than that observed in Jeddah membranes. Distributions of inorganic and organic foulants throughout permeators differ by $7 \%$. Feed ends and brine ends of membranes contain $49 \%$ and $42 \%$ of organic foulants and $51 \%$ and $58 \%$ organic foulants, respectively. Al Birk plant differs from Jeddah in that most of its fouling content is organic rather than inorganic. The organic fouling content of Jeddah membranes is less than its inorganic fouling content. Though both plants are located on the Red sea, there is a difference in intake depth. The Jeddah plant has a deep intake, and the intake of Al Birk is shallow. Intakes that are deep tend to have better water quality due intakes gravitational filtration and the negligible impact of benthic disturbance from storms or tides on water quality parameters.

The use of MPA provides a quantitative understanding of membrane fouling of CTA-HFF membranes. Used in conjunction with known analytical techniques, MPA is a powerful tool for obtaining a quantifiable biological, organic and inorganic profile of membrane fouling for single elements or membranes in series. Though further investigation of its application and use and optimization are required, results obtained are promising. MPA allows for a direct shift from qualitative to quantitative membrane autopsy exploration for HFF membranes.

\section{Conclusions}

Analysis of SWRO membrane biofilm of the Red Sea reveals the presence of organic and inorganic foulants. Quantitatively, inorganic constituents appeared to be the main fouling component of Jeddah SWRO membranes whereas organic foulants were most abundant in Al-Birk membrane autopsies. At both sites, SEM/EDX analysis revealed abundant percent compositions of carbon and oxygen and silica. Carbon and oxygen are the backbone structures of sugars, 
proteins and fats that may be indicative of biofilm. The presence of silica is not odd due to the shallow intakes of Al-Birk and frequent sandstorms and sand drifts of the region (for deeper intakes such as Jeddah). However, in Jeddah plant, high silica levels in brine membranes are unusual because of their series configuration. Instead of sand, high levels could be from the presence of orthosilic acid from the digestion or breakdown of shelled creatures, which may contribute to the presence and proliferation of diatoms on membranes (as confirmed by SEM/EDX).

The use of MPA provides a qualitative and quantitative look into the cause for HFF membrane fouling. This is essential for exploring the root causes of fouling problems so that relevant remedies can be suggested, studied and implemented. MPA in conjunction with chemical, biological and molecular techniques provides a platform for membrane evaluation with the aim of improving its performance. MPA can provide insight into plant operations, corrosion issues and possible anthropogenic problems that impact membrane performance and longevity.

\section{References}

[1] M. Ishizuka, K. Kimura, T. Matsushiro, O. Yamanaka, F. Kurokawa, S. Kurihara, An Identification Method of a Principal Foulant on Reverse Osmosis Membranes, The International Desalination Association World Congress on Desalination and Water Reuse, Tianjin, China, 2013.

[2] M. Saeed, S. Al-Khamis, E. Al-Thobaiti, G. Ozair, K. Mohammad, S. Al-Harthi, A. Bamhair, Study on the Silt Density Index Problem in the SWCC Jeddah Seawater Reverse Osmosis Plants, Saline Water Conversion Corporation, Technical Report No. TR. 3805/APP 96007, 2005.

[3] A.M. Hassan, A.T.M. Jamaluddin, A.R. Badawi, N. Nada, M.M. Al-Amri, L.M. Bakheet, M.O. Saeed, A. Al-Rubaian,
Engineering Design and Natural Resources Management, 6th Saudi Engineering Conference, Vol. 2, KFUPM, Dhahran, 2002.

[4] Y. Liu, C.H. Yang, J. Li, Influence of extracellular polymeric substances on Pseudomonas aeruginosa transport and deposition profiles in porous media, Environ. Sci. Technol., 41 (2007) 198-205.

[5] T.N. Green, M.O. Saeed, G.F. Al-Otaibi, A.S. Al-Mobaid, Biofouling Process Profile of a Commercial 24 MGD SWRO Plant, Saudi Arabia, IDA World Congress, Perth, Australia, 2011.

[6] W.K. King, C. Tran, G. Zhao, L. Morgan, 2009, Analysis of Polar Compounds in Biological Matrix with LS/MS/MS via Normal Phase LE for Sample Preparation, Tandem Labs, New England, USA, 2009.

[7] V. Matyash, G. Liebisch, T.V. Kurzchalia, A. Schevchenko, D. Schwudke, Lipid extraction by methyl-tert-butyl ether for high-throughput lipidomics, J. Lipid Res., 49 (2008) 1137-1146.

[8] Standard Methods, Method for Organic Chemical Analysis, EPA-625, Base/Neutral Acids, National Technical Information Service, Springfield Virginia, 22161, 1984.

[9] M.O. Saeed, W.L. Teng, I.A. Al-Tisan, M.A. Namazi, Characterization of biofilm bacterial isolated from two distinct seawater reverse osmosis systems in Saudi Arabia, Desal. Wat. Treat., 51 (2013) 1855-1860.

[10] J. Clasessens, A.M. Laverman, Y. van Lith, P. Van Cappellen, Response of Shewanella putrefaciens to $\mathrm{pH}$ stress and possible geochemical implications, Geologica ultraiectina, Mededelingen van De Faculteit Geowetenschappen Universiteit Utrecht, No. 259, Chapter 4, 2006, pp. 55-76.

[11] S. Bonneville, T. Behrends, P. Van Cappellen, C. Hyacinthe, W. Röling, Reduction of colloidal Fe(III) oxyhydroxides by Shewanella putrefaciens: a kinetic model, Geochim. Cosmochim. Acta, 70 (2006) 5842-5854.

[12] C. Hyacinthe, S. Bonneville, P. Van Cappellen, Effect of sorbed $\mathrm{Fe}(\mathrm{II})$ on the initial reduction kinetics of 6-line ferrihydrite and amorphous ferric phosphate by Shewanella putrefaciens, Geomicrobiol. J., 25 (2008) 181-192. 